\title{
Ser parte de. Los cuadros sindicales de la Federación Socialista de Córdoba en los años treinta
}

\author{
Being part of. The union cadres of the Socialist Federation in Córdoba \\ in the thirties
}

\author{
Jessica Blanco ${ }^{* *}$
}

\begin{abstract}
Resumen: El artículo se propone contribuir al conocimiento de los vínculos identitarios entre el Partido Socialista (PS) en Córdoba y los dirigentes de extracción sindical del partido, durante los llamados años treinta. Para la reconstrucción de estas relaciones, primero se analizarán los ámbitos institucionales del gremialismo en la estructura partidaria, fundamentales para explicarnos el espacio que la problemática obrera tenía en los temas de agenda del PS de Córdoba y la consideración que tenía el partido de los trabajadores. Por último, se indagará en el grado de inserción sindical del socialismo. Se considera que las redes construidas y posiciones gravitantes que los dirigentes sindicales tenían entre los cuadros partidarios, son relevantes para explicar la fidelidad de los sindicalistas socialistas al partido y el repudio a los intentos cooptativos del gobierno militar de 1943-1946 y del peronismo.
\end{abstract}

Palabras clave: socialismo, sentido de pertenencia, redes sociales, cuadros sindicales, subjetividades políticas

\begin{abstract}
This article intends to contribute to the knowledge of the identity links between the Socialist Party (PS) in Córdoba and the leaders of union extraction during the thirties. In order to reconstruct these relationships first it will be analyzed the institutional areas of the guild in the party structure; which are fundamental to explain the space that the union problematic had in the topics that PS of Cordoba discussed and the consideration that the workers' party received. Lastly, it will be inquired the degree of syndical insertion of socialism. It is considered that the networks built and the gravitating positions that the syndical leaders had between the union cadres are relevant to explain the fidelity of the socialist supporters to the party and the repudiation to the co-opt intents of the military government of 1943-1946 and the Peronism.
\end{abstract}

Keyworks: Socialism, sense of belonging, social networks, union cadres, political subjectivities

Recibido: 9 febrero 2018

Aceptado: 14 abril 2018

\footnotetext{
**A Argentina. Doctora en Historia, Centro de Investigaciones María Saleme de Burnichón de la Universidad Nacional de Córdoba, Concejo Nacional de Investigaciones Científicas y Técnicas, Escuela de Historia de la Universidad Nacional de Córdoba (Córdoba, Argentina). jessieblanco@yahoo.com.ar
} 


\section{Introducción}

El Partido Socialista (PS) argentino ha sido objeto de estudio primero de militantes y luego desde la historia académica, con trabajos centrados fundamentalmente en su doctrina y base programática; en su acción política -focalizada en la labor parlamentaria-, y en las relaciones e inserción en el sistema de partidos. Sin embargo, las investigaciones que indagan acerca de los otros dos frentes de actuación socialista contra la burguesía en la esfera pública, el cooperativismo y las actividades gremiales, no son tan numerosos. Y en parte esto se explica porque la edad de oro del PS, durante la primera mitad de 1930, coincidió con la mayor representación parlamentaria. Este descollante accionar tal vez haya opacado el interés por el conocimiento de los otros dos ámbitos de acción socialista, menos ejercitados o promovidos desde las cúpulas nacionales del partido y los órganos de prensa.

Los estudios que han vinculado la historia del partido socialista con la del movimiento obrero organizado en la primera mitad del siglo XX nos muestran las tensiones internas en el partido respecto de algunas problemáticas gremiales: posición ante las huelgas, representación institucional y actuación en el interior de los sindicatos, vinculación con las centrales obreras, etc. ${ }^{1}$ En general, estos trabajos parten de una premisa compartida: que la preeminencia en el programa y la pragmática del PS de la vía cultural-educativa, electoral y parlamentaria, en detrimento de la organización de un movimiento obrero, era sintomática de una relación conflictiva, de malentendidos e incomprensiones, en un ámbito que estaba siendo ganado exitosamente por los comunistas y en el que la estructura partidaria del PS parecía no sentirse cómoda pero tampoco interesada por estarlo.

Por otro lado, sociólogos e historiadores como Miguel Murmis y Juan Carlos Portantiero, Juan Carlos Torre, Louise Doyon y Joel Horowitz coinciden en que la "vieja guardia sindical", es decir dirigentes prestigiosos y con una larga militancia tanto en el socialismo, sindicalismo, anarquismo y en menor medida el comunismo, constituyó el principal respaldo obrero a Perón, motivada en los años de frustraciones transitados y en la rapidez con la que el Estado le otorgaba antiguos reclamos antes de solicitarlos. Estas

\footnotetext{
${ }^{1}$ María Cristina Tortti, "Clase obrera, partido y sindicatos: estrategia socialista en los años '30”, Serie Cuadernos de Historia Argentina, Buenos Aires, Editorial Biblos, 3, 1989; Hernán Camarero, "El Partido Socialista de la Argentina y sus espinosas relaciones con el movimiento obrero: un análisis del surgimiento y disolución del Comité de Propaganda Gremial, 1914-1917”, Izquierdas, Revista del IDEA-USACH, 22, Santiago de Chile, enero de 2015, 158 - 179; Ricardo Martínez Mazzola, "La neutralidad como problema y como solución. La política gremial del Partido Socialista después de la ruptura sindicalista", Identidades, Universidad Nacional de la Patagonia San Juan Bosco, 1, Comodoro Rivadavia, 2011, 2-20; Lucas Poy, "El Partido Socialista y las huelgas: una relación incómoda. Un análisis de las posiciones partidarias en los primeros años del siglo XX", Archivos de historia del movimiento obrero y la izquierda, CEHTI, 6, Buenos Aires, 2015, 31-51; Diego Ceruso, "Apuntes acerca de la experiencia sindical del Partido Socialista argentino entre 1930 y 1943”, Hernán Camarero y Manuel Loyola (eds.), Política y cultura en los sectores populares y de las izquierdas latinoamericanas en el siglo $X X$, Santiago de Chile, Ediciones de la Internacional del Conocimiento Ariadna Ediciones (e-book), 2016, 171-188; Diego Ceruso, "El Partido Socialista y la cuestión gremial. Debates internos durante la primera mitad de la década infame", Archivos de historia del movimiento obrero y la izquierda, V:10, Buenos Aires, marzo 2017, 119-139; Diego Ceruso, "El Partido Socialista y el movimiento sindical tras la conquista de la Confederación General del Trabajo (1935-1937), Páginas, 9:20; Rosario, mayo-agosto 2017, 131-146.
} 
explicaciones enfatizan el economicismo y la elección racional de la mayoría del espectro sindical, que secundó públicamente las reformas sociales y adhirió a la política interna y externa del gobierno, a cambio de concesiones y a costa de la pérdida de la autonomía y de sus tradiciones ideológicas.

Sin desconocer la relevancia de estos factores, que se apoyan en los beneficios económicos y sociales concretos que significó el peronismo -sobre todo para el trabajador de a pie, sindicalizado o no-, y en las posibilidades políticas que se les abrieron a los dirigentes sindicales, mi prisma analítico pretende complejizar estas causalidades atendiendo a la faz identitaria de la configuración de las subjetividades políticas. En otras palabras, a la hora de explicar el apoyo sindical al peronismo en conformación, no solo deben tenerse en cuenta los intereses económicos sino también la identificación con el discurso peronista. Al respecto, Daniel James argumentó que la base de la atracción específicamente política del peronismo radicaba en la apelación a los trabajadores como ciudadanos sociales y en la valoración como tales, en un lenguaje que eran capaces de entender. $^{2}$

En otro trabajo he demostrado la posición refractaria de los dirigentes sindicalistas socialistas y comunistas de Córdoba ante los intentos cooptativos del gobierno militar de 1943-1946 y del peronismo. ${ }^{3}$ El interés de este artículo es buscar explicaciones a este comportamiento, siguiendo la línea de James. Es por ello que, para el periodo previo al peronismo, considero que los espacios que los dirigentes sindicales de origen trabajador ocuparon en la Federación Socialista Cordobesa (FSC), los flujos de información que manejaron y los círculos de sociabilidad que conformaron en su interior, influyeron en el tipo de interpelación que el partido hizo a los trabajadores. En un contexto de competencia a nivel discursivo y en menor medida de prácticas de carácter obrerista, tanto desde el comunismo como del radicalismo gobernante, estas vinculaciones FSC-mundo del trabajo se tornan claves para explicarnos la fidelidad de los sindicalistas socialistas al partido y el repudio a los intentos cooptativos del gobierno militar de 1943-1946 y del peronismo. ${ }^{4}$ Con interpelación me refiero a aquella acción que reclama del otro al tiempo que lo habilita como un interlocutor válido. Esto genera compromiso e inclusión, ya que significa hacerlo parte de, ya sea de un proyecto, un espacio o discusión que son así considerados comunes o compartidos. Ahora bien, se puede interpelar a un sujeto o grupo social de acuerdo a su rol en el sistema político, como ciudadano; en la estructura de mercado, como consumidor; a nivel productivo, como masa laboral, etc. ¿Existió esa interpelación por parte de los

\footnotetext{
${ }^{2}$ Daniel James, Resistencia e integración. El peronismo y la clase trabajadora argentina, 1946-1976, Buenos Aires, Siglo XXI, 2005 [1988].

3 Jessica Blanco, "Del protagonismo al ocaso. Las dirigencias sindicales comunistas de Córdoba ante la irrupción del peronismo (1936-1948)", Izquierdas, Instituto de Estudios Avanzados de la Universidad de Santiago de Chile, 28, julio de 2016, 13-17.

4 Por una cuestión de espacios, la competencia con el comunismo y el radicalismo gobernante no será trabajada aquí, pero puede consultarse en Jessica Blanco, "El Partido Socialista, el sindicalismo y las competencias en torno del obrerismo en la Córdoba radical (1936-1943)", ponencia presentada en VIII Reunión del Comité Académico de Historia, Regiones y Fronteras, Asociación de Universidades Grupo Montevideo (AUGM), Montevideo, 2017.
} 
partidos de izquierda, y más específicamente del PS, a los trabajadores? En caso afirmativo, ¿en calidad de qué?

En este sentido, el artículo se propone contribuir al conocimiento de los vínculos identitarios entre los partidos de clase, específicamente el socialismo en Córdoba, y los dirigentes de extracción sindical del partido, durante los años de mayor plenitud representativa y los dos gobiernos radicales (1936-1943). Esta década de 1930 extendida está jalonada por los dos primeros golpes de estado que sufrió el país. En su primera parte, dentro del sistema de partidos para el socialismo significó la mayor representación parlamentaria de su historia, interrumpida por el levantamiento de la abstención radical. A nivel interno, en 1937 el partido sufrió la escisión de un sector autodenominado Partido Socialista Obrero (PSO) que, entre otras exigencias, solicitaba un compromiso sindical partidario más activo.

El caso de Córdoba lo abordo no desde la perspectiva analítica del estudio de caso, o por su nivel de representatividad del "interior" del país, en contraposición a la historia "nacional" centrada empíricamente en Capital Federal, sino porque considero que la pequeña escala puede ayudar al análisis de la operativización de variables que no son fáciles de aprehender. Así, analizar Córdoba es útil por su generalización en clave de validez, más que de representatividad..$^{5}$ Este caso es válido no porque nadie estudió el socialismo en Córdoba y es importante reconstruir sus peculiaridades, sino que se justifica por lo que esta escala nos puede decir sobre el desarrollo del socialismo argentino en torno a la problemática obrera. Y no solamente viendo los órganos oficiales del partido, sino también lo que la misma estructura partidaria y visibilidad de cuadros nos está mostrando acerca del lugar de los trabajadores para el PS. Lo anterior claro no implica desconocer lo que son particularidades del desarrollo del socialismo en Córdoba, ${ }^{6}$ que influyen al momento del análisis, como es la ausencia de intelectuales entre los principales cuadros en la configuración primigenia del partido o la centralidad referencial que se construyó en torno a la figura del asesinado José Guevara, como luego veremos.

En concreto, me pregunto acerca de las disposiciones normativas, discursivas y prácticas de los cuadros socialistas en los años treinta para constituir a la FSC en referente de los sectores trabajadores y del movimiento obrero organizado. Así, el eje está puesto en los discursos y las prácticas que buscaron como interlocutores a los trabajadores y de qué manera contribuyeron a la conformación de subjetividades políticas.

Para la reconstrucción de estas relaciones, me centraré en los ámbitos institucionales que tenía el gremialismo en la estructura partidaria local (comisiones sindicales, voz y

\footnotetext{
5 Bernard Lepetit, "De la escala en historia", Jacques Revel (dir.), Juegos de escalas: experiencias de microanálisis, Buenos Aires, UNSAM, 2015 [1996], 112.

${ }^{6}$ Un trabajo histórico que parte de la perspectiva de una identidad diferenciada del socialismo en Córdoba es el de Dujovne. Alejandro Dujovne, "El Partido Socialista de la provincia de Córdoba 1933-1936. Una lectura política desde el periódico Tribuna Socialista", Documento de trabajo $n^{\circ} 2$, Córdoba, Publicación de la Maestría en Partidos Políticos y el Archivo de la Palabra del CEA-UNC, 2003. Un abordaje más tangencial del PS en Córdoba en los treinta en la reconstrucción de las relaciones entre conservadores, radicales y partidos de izquierda en Tcach, César, "Un radicalismo exitoso en la Argentina de los treinta. El caso del sabattinismo cordobés”, Boletín Americanista, 57, Barcelona, 2007, 133-156.
} 
representación obrera en actividades proselitistas, cargos partidarios y en las elecciones gubernativas). Considero que esta variable es fundamental para explicar el espacio que la problemática obrera tenía en los temas de agenda de la FSC y la interpelación que hacía el partido de los trabajadores, otras variables que analizaré. Por último, atenderé sucintamente al grado de inserción sindical del socialismo.

\section{Los espacios del gremialismo en la FSC. El sindicalismo en la política, la política desde el sindicalismo}

Los pilares de transformación social del socialismo contra la burguesía se concentraban en la acción política, las actividades gremiales y el fomento del cooperativismo. En la historia del socialismo argentino, la primera práctica constituía la arista más gravitante, puesto que se consideraba que el cambio social podría darse a través del camino reformista del parlamentarismo y el legalismo. Justamente, la mayor representación parlamentaria del partido llegó a su plenitud en la primera parte del periodo de este estudio, en gran parte debido a la abstención radical.

La línea hegemónica del partido, heredera de las tesis de Juan B. Justo, concebía las actividades políticas y gremiales relacionadas pero autónomas. Sin embargo, la articulación de ambas esferas fue uno de los nudos problemáticos que trasuntó la historia del socialismo argentino y motivó varias escisiones, como la sindicalista de 1906, la de 1917-1918 de la que surgirá el Partido Comunista (PC) y la de mediados de la década de 1930, que dará origen al PSO. Las dos últimas fueron promovidas por sectores de izquierda que infructuosamente reclamaban mayor presencia del socialismo en las filas trabajadoras y representación obrera en cargos partidarios y gubernamentales.

En los años treinta, el viraje de la estrategia política hacia la preeminencia de la acción parlamentaria en detrimento de la inserción sindical en el PS fue notable -aunque no sin conflictos- a nivel de espacios institucionales y de cuadros. ${ }^{7}$ Así lo evidencia la subsistencia, a inicios de la década, de solo cinco comisiones de oficios entre más de quinientos centros, los lugares relegados que los dirigentes sindicales socialistas de la Confederación General del Trabajo (CGT) tenían en el partido, ${ }^{8}$ o incluso en conmemoraciones emblemáticas como el $1^{\circ}$ de mayo; el repaso por los temarios de sus Congresos nacionales y del órgano de prensa La Vanguardia, la composición de sus direcciones partidarias y la consideración que tenían de los trabajadores. Sin embargo, en esta materia la FSC parece no seguir la línea nacional del partido, probablemente debido al carácter plebeyo de su composición.

\footnotetext{
${ }^{7}$ Ceruso, 2017b, op. cit.

${ }^{8}$ Tortti, op. cit, 13; Hugo del Campo, Sindicalismo y peronismo. Los comienzos de un vínculo perdurable, Buenos Aires, Clacso, 1983, 61.
} 


\section{La gravitación de los cuadros de origen sindical en la estructura partidaria}

El peso que los cuadros sindicales tenían en las redes de relaciones al interior del partido, que influían en su presencia tanto en la Junta Ejecutiva (JE) de la Federación como en el equipo editorial del órgano de prensa Tribuna Socialista, fueron fundamentales para marcar en el ADN de la Federación ciertas características plebeyas.

La conformación de los órganos ejecutivos del PS era el resultado del voto general y secreto de los cotizantes, es decir los afiliados con la cuota al día. En el caso de la JE de la FSC, entre 1933 y 1935 estaba compuesta por el secretario general Santiago Stieben (abogado), el secretario de actas Francisco Pérez Marcen (s/d); el tesorero Armengol Juliani Deanquín (sastre), y los vocales Bernardo Zaffrani (empleado de comercio), José Guevara (empleado de farmacia), Juan Cirulli (sastre) y Arturo Da Rocha (profesor). Durante el bienio 1935-1937 integraron la Junta el secretario general Miguel J. Ávila y el de actas Juan Cirulli (sastres); el tesorero Francisco Pérez Marcén, el protesorero Gustavo Bonnet; y los vocales Ernesto Monier (ferroviario), Héctor Lucero y Juan P. Pressacco (abogado, de Río Cuarto). En julio de 1935 Ávila fue reemplazado por Bonnet, mientras que la secretaría de actas quedó a cargo de Lucero. A fines de 1937, la JE estaba compuesta por siete miembros, cinco de ellos vinculados con el gremialismo: los ferroviarios Luis Monzalvo (secretario general) y Bruno Herrera, y los sastres Juan Corzo, Miguel Ávila y Juan Cirulli. Completaban la junta el médico Bernardo Movsichoff y Francisco Pérez Marcén. En 1940, el número disminuyó a tres (Ávila, Deanquín y Herrera) de ocho.

Por su parte, la Comisión de prensa a cargo del periódico de la FSC, Tribuna Socialista, en sus inicios estuvo bajo la dirección de José Guevara (hasta su muerte, en septiembre de 1933. Luego reemplazado por el comerciante Stegagnini), acompañado por el doctor Santiago Stieben, el en ese entonces estudiante de medicina Movsichoff, Amleto Magris y Esteban Drebich (s/d). En 1935 Da Rocha ocupó su dirección, pero en junio fue sustituido por Magris. La última comisión de prensa conocida hasta 1936, estuvo compuesta por el director Movsichoff; el secretario de redacción Adelmo Montenegro (maestro); el administrador Ávila; y los vocales Magris y Cirulli. ${ }^{9}$

Cabe recalcar que la representación obrera en la dirección de la FSC sobresale en comparación con la del Comité Ejecutivo Nacional del PS. A manera de ejemplo, menciono la composición de los años 1934-1936: Mario Bravo, Joaquín Coca, Enrique Dickman, Fernando Ghio, Héctor Iñigo Carrera, Andrés Justo, Benito Marianetti, Alicia Moreau de Justo, Nicolás Repetto, Adolfo Rubinstein y Fortunato Zabala Vicondo, y como delegados del grupo parlamentario Américo Ghioldi y Silvio L. Ruggieri. ${ }^{10}$ Entre la mayoría de abogados y médicos, de los que cuento con datos, solo Coca tenía vinculaciones sindicales. ${ }^{11}$

\footnotetext{
${ }^{9}$ Tribuna Socialista, 1 de mayo de 1933, pp. 2 y 5; 20 de junio y 4 de julio de 1935, p. 7 y 17 de julio de 1936, p. 3; Federación Socialista Cordobesa, XI Congreso Ordinario (XIII Provincial) que se realizará en la ciudad de Córdoba, los días 1 y 2 de abril de 1939, p. 9; Partido Socialista, XXXIII Congreso Nacional (XXV Congreso Ordinario), Buenos Aires, julio de 1940, Talleres Gráficos La Vanguardia, 84.

${ }^{10}$ Partido Socialista, XXIV Congreso Ordinario (XXXII Congreso Nacional), Buenos Aires, junio de $1938,26$.

${ }^{11}$ Horacio Tarcus (dir.), Diccionario Biográfico de la Izquierda Argentina, Buenos Aires, Emecé Editores, $2007,135$.
} 
Las diferencias también se producen a nivel de la dirección de los estratégicos órganos de prensa del partido. La Vanguardia estuvo dirigida durante esos años por los profesionales Enrique Dickmann (1930-31; 1940-1942), Rómulo Bogliolo (1932-33; 193639 y 1940), a cargo también de la revista teórica Revista Socialista y el abogado Mario Bravo (1939-40). Entre 1933 y 1934 llegó a ser director de la misma el periodista Luis Pena, lo mismo que Ghioldi -1933-34; 1942-44-. ${ }^{12}$ Algunos de ellos fueron pensadores fundamentales que marcaron la línea hegemónica del partido desde los órganos partidarios, como Dickmann, Ghioldi o Bravo. Como mencioné más arriba, en su corta vida de cuatro años, Tribuna Socialista contó con varios directores de diverso origen socioprofesional: Guevara, Stegagnini, Da Rocha, Magris y Movsichoff. Lo mismo que los directores de La Vanguardia, los de Tribuna Socialista desempeñaban cargos partidarios y legislativos en el partido, pero ninguno de ellos se erigió como un referente teórico local.

Al igual que a nivel nacional, en Córdoba la primera mitad de la década de 1930 constituyó la edad de oro en la representación parlamentaria socialista. Así, en las elecciones de noviembre de 1931 el PS y el Partido Demócrata Progresista conformaron la Alianza Demócrata Socialista. Si bien es cierto que los candidatos al Ejecutivo eran intelectuales reformistas (Gregorio Berman para gobernador y Deodoro Roca para intendente) que se habían incorporado hacía meses al partido, los cargos efectivamente ganados quedaron en manos de un grupo de dirigentes socialmente heterogéneo. De los cinco diputados nacionales, Juan Pressacco, Serapio Molina, Bruno Herrera (hasta enero de 1936), Bernardo Movsichoff y Amleto Magris (hasta abril de 1938), sabemos que el primero era abogado, el tercero dirigente sindical ferroviario y el cuarto estudiante universitario, mientras que el único senador provincial (por el departamento Capital), Arturo Orgaz, era abogado. Los siete diputados provinciales provenían de sectores medios cuentapropistas y asalariados (el comerciante Luis Stegagnini, los empleados de farmacia José Guevara y Argentino Gallegos, los sastres Miguel Ávila y Juan Cirulli, el zapatero Francisco Mulet y el maquinista ferroviario Juan Corzo). Entre los cinco concejales por Capital electos, figuraban el librero José Bizzocchi, Gustavo Bonnet, Salim Constantino, el ferroviario Luis Monzalvo y Francisco Pérez Marcén. ${ }^{13}$

En las elecciones ejecutivas y legislativas de 1931, en la provincia de Córdoba el PS consiguió dos intendencias (Sampacho y Laboulaye), varias concejalías en diez localidades, cinco diputados nacionales, un senador y siete diputados provinciales. Sin embargo, cuatro años después los radicales se sumaron a la competencia electoral y ganaron con el apoyo del PC. El socialismo no pudo revalidar posiciones, perdió cargos legislativos y las dos intendencias. Obtuvo casi 3600 votos, lo que representaba apenas el 1,63\% de los votos emitidos. Una cifra muy alejada de las legislativas de marzo de 1934, en las que, con la

\footnotetext{
12 Ibid, passim.

${ }^{13}$ Tribuna Socialista, 27 de septiembre de 1935, pp. 3 y 15; Federación Socialista Cordobesa, IX Congreso Ordinario (XI Provincial), que se realizará en la ciudad de Córdoba, 26, 27 y 28 de octubre de 1934. Informes, pp. 8 y 20; César Tcach, "Crimen político en barrio Güemes", La Voz del Interior, 24 de septiembre de 2013; Gardenia Vidal (dir.), Reseña Biográfica de dirigentes que interpelaron al mundo del trabajo en Córdoba 1900-1950, E-Book, Córdoba, 2014, passim.
} 
abstención radical, había obtenido 20000 votos, pero bastante superior a escenarios pasados en los que el radicalismo participó: 900 votos en 1928 y 1200 en $1930 .^{14}$

Para las elecciones legislativas de 1938, la presencia sindical disminuyó, puesto que como candidatos a diputado nacional fueron elegidos por el voto popular los abogados Orgaz y Pressacco, Magris y el sastre Ávila. En 1940 la tendencia se mantuvo, ya que de los diez candidatos a concejales por el PS para las elecciones, por lo menos cuatro (los sastres Ávila, Juliani Deanquín y Antonio D’ Élía y el ferroviario Herrera) eran dirigentes sindicales. De los seis candidatos a diputado nacional, dos eran abogados (Arturo Orgaz y Ricardo Vizcaya), uno médico (Bernardo Movsichoff) y dos dirigentes sindicales (el sastre Ávila y el ferroviario Monzalvo). Del restante, Magris, solo conocemos que no era profesional. $^{15}$

Como observamos, entre los trece cargos legislativos nacionales y provinciales obtenidos en 1931, solo dos eran ocupados por profesionales y por lo menos siete correspondían a dirigentes sindicales o miembros del asalariado. Es un porcentaje importante si lo comparamos con las bancas de diputados nacionales obtenidas por el PS de Capital Federal para 1932-1936, ocupadas por varios referentes del PS argentino: el obrero tornero Jacinto Oddone, los periodistas Américo Ghioldi, Juan Antonio Solari y José Luis Pena, los médicos Nicolás Repetto y Enrique Dickmann, el contador Rómulo Bogliolo y el abogado Carlos Moret. ${ }^{16} \mathrm{Si}$ bien algunos de ellos tenían un origen humilde y solo contaban con estudios básicos, ninguno estaba en ese momento vinculado a alguna organización sindical.

Por último, si nos enfocamos en la presencia socialista en los actos públicos, en cuanto a problemáticas tratadas las temáticas de los actos, mitines y conferencias se concentraron no solo en la preocupación por la crisis económica, el gravamen de los latifundios en las zonas rurales, los conflictos laborales, la organización y la libertad gremiales, sino también en los vicios de la "política criolla", la defensa de la democracia y la oposición a los regímenes autoritarios. ${ }^{17}$ Los oradores de estos eventos compartían el ocupar cargos legislativos, tanto nacionales como provinciales. A veces, sobre todo en el interior de la provincia o en las seccionales de la ciudad de Córdoba, eran acompañados en las gradas por militantes vecinos del lugar. Queda evidenciado que la elección de los oradores se restringía a aquellos dirigentes cuyos cargos les redituaban una alta exposición y visibilidad públicas, con actividades de control y formulación legislativa, consideradas centrales entre las prácticas del socialismo argentino. De todas maneras, la elección

\footnotetext{
14 Roberto Ferrero, Del mutualismo al Cordobazo. Breve historia del movimiento obrero en Córdoba, Córdoba, Ediciones del Cepen, 2009, 94; Tribuna Socialista, 5 de diciembre de 1935, pp. 4- 6.

${ }^{15}$ Federación Socialista Cordobesa, XI Congreso Ordinario (XIII Provincial) que se realizará en la ciudad de Córdoba, los días 1 y 2 de abril de 1939, 24; La Voz del Interior, 10 de marzo de 1940, p. 7.

${ }^{16}$ Tarcus, op. cit.

17 Tribuna Socialista, 15 de mayo de 1933, p. 6; 20 de marzo de 1935, pp. 6-7; 1 de mayo de 1935, p. 5; Tribuna Socialista, 15 de enero de 1935, p. 1; Federación Socialista Cordobesa, XI Congreso Ordinario (XIII Provincial) que se realizará en la ciudad de Córdoba, los días 1 y 2 de abril de 1939, 12-13; Partido Socialista, XXXIII Congreso Nacional (XXV Congreso Ordinario), Buenos Aires, julio de 1940, Talleres Gráficos La Vanguardia, 84; El País, 1 de noviembre de 1941, p. 4.
} 
también encubría motivaciones de ahorro económico y temporal: los legisladores, en su condición de tales, gozaban de pase ferroviario. ${ }^{18}$

En este punto, la procedencia social o la trayectoria laboral del legislador era una cuestión secundaria, excepto en conmemoraciones especiales, como el $1^{\circ}$ de mayo. El cargo legislativo avalaba al político como autoridad y le suponía idoneidad, a la vez que servía como criterio para eliminar probables competencias en la exposición pública. Al respecto, son elocuentes las palabras de Fermín Simón sobre los jóvenes en el movimiento socialista y el acceso a las tribunas como oradores:

Muchos compañeros se lamentar [sic] de no ser tenidos en cuenta como oradores, ¿pero realmente ocupan la tribuna? ¿Se han empeñado en dominar un problema? ¿Concurren a los actos en la medida de que éstos sean para ellos una escuela? ¿leen diariamente "La Vanguardia"?¿Están bien informados del pensamiento y criterio socialista sobre los múltiples y complejos problemas que plantea la hora social? Y si integra alguna o algunas comisiones, está seguro de ser útil $?^{19}$

En definitiva, de las diferencias en la conformación socioprofesional de los órganos directivos y los cargos electivos del PS nacional y de la FSC se desprende que, en ambos casos, para los cargos ejecutivos los cotizantes elegían figuras de prestigio intelectual y con un capital cultural relevante, expresado en títulos de grado y posgrado. Sin embargo, y a diferencia del nivel nacional, en la FSC se destacaba el componente obrero y la representatividad sindical de sus cuerpos electivos, lo que brindaba al organismo un carácter para nada elitista, como parece ser la composición del PS nacional. Esto nos está hablando de electores que, más allá de su perfil socioeconómico, votaban a dirigentes de variada extracción social, que son los que finalmente terminaron dibujando el perfil y características de la federación. Ahora bien ¿Por qué algunos nombres se repetían en los diferentes ámbitos de poder del partido? ¿Por qué lograban ser los más votados? Ahondar desde la perspectiva de las redes sociales en las tramas de sociabilidad que llevaron a unos dirigentes a tener mayor visibilidad y gravitación decisional en el partido puede servirnos para pensar los contornos del socialismo argentino, más allá del caso de Córdoba.

\section{La FSC como un partido plebeyo y popular}

Hasta aquí he caracterizado la composición socioprofesional de los órganos electorales y partidarios de la FSC, resaltando la mayor heterogeneidad y representatividad sindical respecto de la cúpula nacional del partido. Esto nos avala para afirmar que el socialismo local era más coherentemente un partido de y para los trabajadores que su homólogo nacional. Empero, de la adscripción socioprofesional de los actores no deberían

${ }^{18}$ XX Congreso Ordinario (XXV Congreso Nacional). Informes Comité Ejecutivo Nacional, Grupo Parlamentario y Comisión de Prensa, Talleres Gráficos La Vanguardia, Buenos Aires, 1929, 76.

${ }^{19}$ Tribuna Socialista, 21 de agosto de 1936, p. 7. 
desprenderse a priori determinados intereses o comportamientos, aislados de un contexto de interacciones.

Llegados a este punto cabría preguntarse cuáles fueron los procesos sociales que llevaron a este perfil más popular del socialismo vernáculo: ¿el producto de qué relaciones e intercambios entre actores con qué capital social es la FSC de los años treinta? Al respecto, resulta útil pensar en las redes sociales como instrumentos operativos para la reconstrucción de los sistemas de relaciones entre los actores sociales. Las redes sociales son complejos sistemas de vínculos que permiten la circulación de bienes y servicios, materiales e inmateriales, en el marco de las relaciones mantenidas entre sus miembros. ${ }^{20}$ Para hablar de redes es fundamental que existan intercambios en su interior, que se traduzcan en vínculos, y que éstos sean transversales (sino serían binarios). Las redes funcionan a través de círculos sociales o de sociabilidad, en los que sus miembros se reconocen como tales. La integración voluntaria a un grupo y el sentido de pertenencia, que influye en los comportamientos, son centrales, pero también la aceptación de los incorporados por parte de los miembros previos. En la red también cabe distinguir distintas calidades de vínculos, más fuertes o más débiles, de acuerdo a la relevancia de los intercambios realizados y la centralidad de los actores involucrados. ${ }^{21}$

Del relevamiento de la composición dirigencial de la FSC entre las décadas de 1920 y 1940 se desprende la imagen de un partido que es manejado por cuadros de dilatada trayectoria, como Pressacco, Stegagnini, Pérez Marcén, Mulet, Corzo o Guevara, los tres últimos vinculados a los sectores trabajadores. A fines de los años veinte, la Federación se vio afectada por la escisión que dio lugar a la fundación del Partido Socialista Independiente, a la que adscribieron sus tres diputados nacionales. Si bien se produjo una sensible disminución de centros y afiliados, ${ }^{22}$ luego del golpe de Estado de 1930 el PS de Córdoba recibió, al igual que los de otros puntos del país, la filiación y participación política de parte de la intelectualidad reformista universitaria, disidentes con (y/o expulsados por) la política educativa de intervención en las universidades. ${ }^{23}$ Según Alejandro Dujovne, se acercaron al partido local, con distinto grado de compromiso, Arturo y Jorge Orgaz, Deodoro Roca, Gregorio Bermann, Ceferino Garzón Maceda, Enrique Barros, Gumersindo Sayago, Ricardo Vizcaya y Saúl Taborda. ${ }^{24}$ Sin embargo, en Córdoba este paso resultó ser fugaz, con una influencia ideológica difícil de evaluar. Cabe señalar que, más allá de sus candidaturas casi imposibles a los cargos ejecutivos (como las de Bermann y Roca de 1931 y la de Orgaz de 1935 y 1937), en los años estudiados los referentes de la intelectualidad cordobesa reformista ocuparon espacios poco gravitantes en

\footnotetext{
${ }^{20}$ S. Nadel y J. C. Mitchell, citados en Michel Bertrand, "De la familia a la red de sociabilidad", Páginas, Universidad Nacional de Rosario, 4:6, Rosario, 2012, 62.

21 Ibid, 64-66.

22 XX Congreso Ordinario (XXV Congreso Nacional). Informes Comité Ejecutivo Nacional, Grupo Parlamentario y Comisión de Prensa, Talleres Gráficos La Vanguardia, Buenos Aires, 1929, 101.

${ }^{23}$ Ricardo Martínez Mazzola y Sebastián Giménez, "Del claustro a la tribuna. Los universitarios reformistas y los partidos políticos en la década del 30", Cuatrocientos años de la Universidad Nacional de Córdoba. Libro conmemorativo. Tomo II, Universidad Nacional de Córdoba, Córdoba, 2013, 87-106.

24 Alejandro Dujovne, "El Partido Socialista de Córdoba y la Reforma Universitaria, 1917-1948”, Marcela González (ed.), Poder Político y Estrategias Sociales. Córdoba 1900-1950, Córdoba, EDUCC, 2004, 193234.
} 
el partido, tanto a nivel partidario, de representación parlamentaria, en mitines y actos, y en la misma prensa partidaria. Solo podemos mencionar como excepción a Arturo Orgaz, de proficua labor legislativa de índole social.

Asimismo, por esa época comenzaron a aparecer en las listas dirigenciales nuevos nombres que pronto ganarían espacios relevantes en el partido: Miguel Ávila, Bruno Herrera, Luis Monzalvo, Bernardo Movsichoff, y los ex PC Pedro Magallanes y Armengol Juliani de Anquín. ${ }^{25}$

Llama la atención que, salvo Orgaz, pero desde su condición de senador, los intelectuales reformistas cordobeses advenedizos en el socialismo, no aparecían como asiduos oradores ni redactores en Tribuna Socialista. Esta se direccionó a difundir noticias locales de índole obrera y agraria, en detrimento de la reproducción del pensamiento de teóricos socialistas nacionales o locales. Orgaz por ejemplo, escribía en el periódico para difundir su obra legislativa, no como pensador. Como señaló Dujovne, también es llamativa la casi nula presencia de artículos sobre la realidad universitaria. ${ }^{26}$ Tampoco la FSC contaba -ni parecía querer contar- con una trayectoria teórica, de pensadores que reflexionaran e influyeran sobre el partido, como un Juan B. Justo, un Reppeto, un Dickmann o un Ghioldi. Todo lo anterior es sintomático de la poca gravitación que estos intelectuales tuvieron como tales en la Federación.

Las lógicas de interacción de la FSC parecían ir a contramano de una sociedad que todavía creía en el prestigio que brindaba el abolengo o un título o cargo universitario. Así, el capital cultural y la reputación nacional en el plano político intelectual que detentaban como credenciales los reformistas cordobeses se estimaron poco valiosos para el socialismo local, en el que pesaban los flujos de información y las redes conformados varios años atrás. Y precisamente son las redes y ciertos perfiles más atentos a lo popular de algunos de estos intelectuales los que pueden llegar a explicarnos por qué Orgaz y Garzón Maceda ocuparon un lugar más destacado en el partido, respecto de Roca y Bermann, por ejemplo.

Estos cuatro intelectuales reformistas contaban con una trayectoria asociativa e inserción universitaria en parte compartida desde la segunda década del siglo XX, aunque en el perfil de Orgaz se destacaba cierto interés por lo popular y contacto con lo plebeyo. ${ }^{27}$ $\mathrm{Su}$ tesis doctoral en Derecho se tituló Las muchedumbres. Ensayo de sociología colectiva (1914). Pero lo más interesante es que fue presidente del club de fútbol Belgrano, entre 1905 y 1911 y de la Liga Cordobesa de fútbol entre 1924 y 1928, coincidiendo en ámbitos de sociabilidad y responsabilidades dirigenciales con Francisco Pérez Marcén, un histórico de la FSC vinculado al club Talleres, y con Miguel Ávila, quien hacia 1928 formaba parte de la comisión del Club Atlético San Isidro, de la localidad de San Francisco. ${ }^{28}$ Es probable

\footnotetext{
${ }^{25}$ Sobre las trayectorias de Armengol Juliani de Anquín y Pedro de Magallanes, consúltese Vidal, op. cit., $156-158$ y $160-161$.

${ }^{26}$ Dujovne, 2004, op. cit.

27 Acerca de los perfiles de las figuras de Roca, Bermann y Orgaz puede consultarse el proyecto virtual Culturas Interiores. Un archivo de la cultura de Córdoba. http://culturasinteriores.ffyh.unc.edu.ar/inicio.jsp

${ }^{28}$ Requena, Pablo; voz Arturo Orgaz; on line; disponible en http://culturasinteriores.ffyh.unc.edu.ar/ifi002.jsp?pidf=AM3M3A\&po=DB [06/02/2018]; http://www.clubtalleres.com.ar/talleres-el-primer-club-argentino-en-viajar-a-paraguay/; Club Atlético San Isidro, 1970.
} 
que estas características de su perfil y las casi seguras vinculaciones futbolísticas con dos referentes de la FSC hayan ayudado a su integración al partido. De Ceferino Garzón Maceda sabemos mucho menos. También abogado y docente universitario en Historia Económica, es reconocido como un historiador colonial. Su presencia se mantuvo en la FSC, sin embargo su proyección fue mucho menor que la de Orgaz.

Respecto de Roca, tanto su tesis doctoral como sus escritos posteriores versaron acerca de política internacional y antiimperialismo, y sobre Universidad y reformismo. Por último, Bermann era un médico psiquiatra y docente universitario de las facultades de Medicina y Derecho. Interesado en la criminología, se le encomendó una investigación sobre menores delincuentes que en 1932 tituló "Los menores abandonados y delincuentes en Córdoba. ${ }^{29}$ Escribió varios libros y artículos, ninguno vinculado con las problemáticas obreras. Ambos coincidieron en el compromiso antifascista institucionalizado. La pertenencia o cercanía de ambos con el PS, que se inauguró con sus candidaturas a cargos ejecutivos en 1931, pareció ser incómoda, puesto que a los años acercaron posiciones con el comunismo. Tal vez por ello es que la FSC constituyó para ellos un ámbito de sociabilidad e influencia pública marginal respecto de otros espacios: frentes antiguerreros y antifascistas como la revista Flecha (1935-1936), el órgano del Comité Pro Paz y Libertad de América, entidad liderada por Bermann, Roca y Enrique Barros; ${ }^{30}$ la Agrupación de Intelectuales, Artistas, Periodistas y Escritores; la Liga Argentina por los Derechos del Hombre y el Comité de Ayuda al Pueblo Español (CAPE).

En definitiva, lo desarrollado hasta aquí nos muestra que en el periodo estudiado, los dirigentes sindicales tuvieron espacios expectantes y de poder en una FSC que adrede parecía rechazar las grandes teorizaciones, como forma también de asirse a una tradición aintelectual en construcción, posición que seguramente influyó en la interpelación más inclusiva e igualitaria del partido hacia los trabajadores. En efecto, la presencia y gravitación que los cuadros sindicales tenían tanto en la Junta Ejecutiva de la Federación como en el equipo editorial de Tribuna Socialista hicieron posible la existencia de dispositivos de defensa y representación gremial y la visibilidad de la temática obrera en el periódico.

\section{Los espacios de las problemáticas obreras en la estructura partidaria y en el órgano de prensa}

En términos de estructura partidaria, al igual que a nivel nacional en el PS de Córdoba existía un Comité de Defensa Obrera, para la ayuda jurídica de los trabajadores. En 1933, y por resolución del último congreso provincial, la Junta Ejecutiva de la Federación designó a uno de sus miembros y a cuatro afiliados para la conformación de una

\footnotetext{
${ }^{29}$ Requena, Pablo; voz Gregorio Bermann; on line; disponible en http://culturasinteriores.ffyh.unc.edu.ar/ifi002.jsp?pidf=PN6\&po=DB [06/02/2018]

${ }^{30}$ Sobre el contexto de aparición de Flecha y su significado en la cultura política de izquierda argentina véase Martín Bergel, "Flecha, o las animosas obsesiones de Deodoro Roca", Deodoro Roca. Obra Reunida. Vol. IV. Escritos políticos, Córdoba, 2012, 23-69. En el caso de Bermann, su relevancia dentro del partido aumenta desde 1936, luego de la incorporación del PS en el Frente Popular. El Socialista, 25 de julio de 1936, p. 1.
} 
Comisión Gremial Socialista. Estaba compuesta por los sindicalistas Pedro Magallanes (obrero del calzado), Miguel Ávila (sastre), Ernesto Monier (ferroviario), Simón Juan -comerciante-. Por su actividad, renuncia aduciendo incompatibilidad) y Armengol Juliani Deanquín (sastre) por la Junta. Esta Comisión Gremial constituía una originalidad del partido en sus vínculos con el mundo sindical, puesto que entre sus funciones se destacaban las de constituir sindicatos, intensificar la propaganda gremial en los ya organizados, confeccionar estadísticas del trabajo por gremios y publicar un boletín con el resultado de las mismas. ${ }^{31}$

En este punto, y con visos comparativos, vale la pena detenerse en la inserción partidaria y papel cumplidos por la Comisión Socialista de Información Gremial nacional. Ésta había sido creada en 1921 para coordinar las actividades del partido en el ámbito sindical y estaba compuesta por afiliados designados en asamblea, más un representante del Comité Ejecutivo. Es cierto que en la primera mitad de los años treinta en su interior cobró fuerza un sector que bregaba por un vínculo más estrecho entre partido y sindicatos, ${ }^{32}$ pero esta postura no pudo traducirse en un mayor compromiso de la CSIG que fuera más allá de las funciones de publicidad, información, educación, coordinación y formación gremial en los sindicatos. Desde el congreso partidario de 1935, y en el marco de las disputas ganadas a la izquierda partidaria, la temática gremial fue desplazada de la agenda del PS y la CSIG perdió grados de autonomía, al pasar sus miembros a ser designados por el Comité Ejecutivo. Cabe destacar que desde 1940 la Comisión Socialista de Información Gremial nacional denotó en sus funciones un giro hacia un mayor activismo sindical, ${ }^{33}$ que por el momento desconocemos si se plasmó en acciones concretas, al tiempo que en los congresos nacionales vuelve a aparecer la temática gremial. Estos cambios probablemente se relacionen con la reincorporación al partido de los ex afiliados que en 1937 habían formado el PSO.

Por las noticias sindicales de Tribuna Socialista que más adelante señalo y los informes de la Comisión, queda evidenciado que ésta logró cumplir gran parte de los objetivos, constituyendo a la FSC como una referencia insoslayable en la defensa de los intereses proletarios. Por lo menos entre 1933 y 1935, la elección de la Comisión por parte de la JE no significó una sujeción o limitación de acciones, puesto que ambas coincidían en la prioridad sindical del partido.

En definitiva, la Comisión Gremial Socialista (diferente en nombre y funciones de la Comisión Socialista de Información Gremial nacional), el Comité de Defensa Obrera y la difusión de las resoluciones gremiales -que veremos luego- constituyeron parte de la estrategia de inserción del socialismo vernáculo en el movimiento obrero.

El análisis del órgano de prensa de la Federación, Tribuna Socialista (1933-1936), da cuenta de la centralidad que ocupaba la problemática obrera y sindical en sus páginas, seguramente influido por la línea editorial que le imprimió su directorio, socioprofesionalmente heterogéneo. A diferencia de otros órganos de prensa del PS, este periódico quincenal se presentaba como una hoja provincial que priorizaba la problemática local. Por el contrario, las elucubraciones teóricas, las temáticas nacionales o los

31 Tribuna Socialista, 15 de mayo de 1933, p. 6.

32 Tortti, op. cit., 26; Ceruso, 2017b, op. cit., 123-133.

33 Partido Socialista, XXXIII Congreso Nacional (XXV Congreso Ordinario), Buenos Aires, julio de 1940, Talleres Gráficos La Vanguardia, s/p. 
comentarios de los debates parlamentarios no eran muy comunes. Además, se proponía como vocero "del movimiento gremial y cooperativo" y explícitamente definía al partido como organización política de los trabajadores. ${ }^{34}$ Esta preocupación por la faz sindical del partido que aparecía en Tribuna Socialista, era sintomática de los lineamientos que la JE Provincial pretendía darle al partido. Así, en el tercer número se reproducían los artículos de los Estatutos referentes al deber de pertenencia de los afiliados a sus respectivas organizaciones gremiales, como una exigencia de clase, ${ }^{35}$ lo que daba por supuesto el origen trabajador de los militantes.

También contaba con una sección específica titulada "Actividades sindicales", que, a través de la difusión de diferentes conflictos gremiales en diversos puntos de la provincia, resaltaba el compromiso activo de la Comisión Gremial Socialista en la formación de sindicatos, redacción de pliegos de condiciones y gestiones ante las autoridades; así como la inacción de la Oficina (luego Departamento Provincial) del Trabajo y la complicidad de las autoridades políticas y policiales locales con la patronal. A mediados de 1935, el periódico se propuso cronicar las asambleas gremiales y publicar las resoluciones enviadas por los sindicatos, ${ }^{36}$ iniciativa que parece no haberse plasmado, en parte quizá por las dificultades económicas que obligaron a espaciar la salida de Tribuna Socialista.

Por otro lado, el periódico mostraba la responsabilidad concreta del partido a nivel local para con la clase obrera en su actividad parlamentaria, mediante la publicidad de iniciativas de legisladores socialistas cordobeses relacionadas al ámbito laboral urbano y rural: los proyectos nacionales de creación de escuelas técnicas rurales en el interior provincial y de rebaja de arrendamientos, o los provinciales de reconocimiento legal de los sindicatos obreros y de unificación de la Oficina de Trabajo con la de Protección Obrera. ${ }^{37}$

\section{Los destinatarios del mensaje: "trabajadores conscientes, capaces y responsables"}

Ya adelanté quiénes tenían la palabra en la FSC, y desde qué lugar, para qué y a quienes hablaban. Si bien ya mencioné que los equipos editoriales de Tribuna Socialista eran variopintos, tenían en común que exaltaban la vinculación partidaria con el mundo de los trabajadores.

La interpelación a los obreros era en ámbitos concretos de su vida cotidiana, y cuando se abordaba la relación capital-trabajo desde una perspectiva teórica se trataba de artículos transcriptos de publicaciones nacionales. Sin embargo, no todos los trabajadores estaban invitados a sumarse al PS, ya que el llamado se restringía al sector pensante de los proletarios.

\footnotetext{
${ }_{34}^{34}$ Tribuna Socialista, 1 de mayo de 1933; 20 de marzo y 1 de mayo de 1935, p. 2.

${ }^{35}$ Tribuna Socialista, 1 de junio de 1933, p. 4; 15 de enero de 1935, p. 4.

${ }^{36}$ Tribuna Socialista, 4 de julio de 1935, p. 5.

${ }^{37}$ Tribuna Socialista, 4 de julio de 1935, pp. 3 y 5; 18 de julio de 1935, p.3; 27 de septiembre de 1935, pp. 6, 7 y 12.
} 
En su primer número, el periódico declaraba al $1^{\circ}$ de mayo de 1889 como la fecha fundacional del despertar político y sindical no de todos los trabajadores, sino de "la parte más consciente, más digna y más esclarecida." En efecto, se partía del supuesto que los obreros, al estar sumidos en la ignorancia y la pasividad, eran fácilmente explotados. No obstante, se aclaraba que la poca instrucción no significaba en absoluto falta de inteligencia. De ahí se asumía la función de los socialistas de iluminar las mentes obreras y capacitar a las masas. Empero, los medios elegidos no se reducían a las bibliotecas o la transmisión de los principios socialistas a través de la prensa y los cursos de divulgación doctrinaria, sino que, como nos muestra el accionar de la Comisión Gremial Socialista, abarcaban el aprendizaje gremial in situ, con el ejemplo y la guía de "obreros conscientes": los sindicalistas socialistas de extracción proletaria. Si bien en Tribuna Socialista aparecía la sinonimia característica del socialismo con el progreso y la civilización y la cultura modernas, ${ }^{38}$ había una diferencia en la consideración del actor transformador. En efecto, porque se afirmaba que la salida para cambiar la realidad era el compromiso del obrero, quien a través de la sindicalización, la incorporación a la cooperativa y la adhesión al socialismo -entendido como partido de su clase-, podría lograr la emancipación con la acción y el esfuerzo coordinado de pares. ${ }^{39}$ Este punto es relevante, porque significa un distanciamiento y diferenciación con el ideal socialista iluminista justista, de educar al proletariado para hacer de los trabajadores seres políticos maduros y pensantes, dignos y responsables de un voto que, si consciente, debía ir dirigido al socialismo. Como ejemplo, cito el artículo "El deber de los socialistas" de La Vanguardia, que en 1942 reproducía de manera casi idéntica lo que Justo había establecido como base del partido varias décadas atrás:

Los socialistas tienen una alta y noble tarea que realizar en el movimiento gremial proletario. Tarea de educación societaria, de esclarecimiento de la conciencia histórica de clase, de elaboración de la madurez política, e infundir espíritu al cuerpo inerte de las masas laboriosas. (...) Y en el campo cultural la función de los socialistas es ilimitada y trascendente. Llevar al seno del pueblo las verdades científicas, embellecer su vida con el arte, destruir los prejuicios y las supersticiones, es hacer del ser humano un ente pensante y sensible. ¡Qué alta y noble tarea! ${ }^{40}$

Mientras en este pasaje el gestor del cambio era el socialista que iluminaría las mentes del pueblo trabajador, y a la manera del Dr. Frankenstein con su criatura, le infundiría una vida pensante a través de la educación, en Tribuna Socialista quedaba claro

\footnotetext{
${ }^{38}$ Dujovne, 2003, op. cit., 8-9.

${ }^{39}$ Tribuna Socialista, 1 de mayo de 1933, pp. 1, 3 y 4; 1 de junio de 1933, p. 3; 1 de mayo de 1935, p. 2.

40 Artículo de La Vanguardia, reproducido en el periódico de la Federación Socialista Mendocina El Socialista, 1 de enero de 1942, p.1. Luego de la muerte de Justo, esta concepción fue sostenida por numerosos dirigentes y publicistas, como Enrique Dickman, Nicolás Repetto y Jacinto Oddone, entre otros. Maria Cristina Tortti, El viejo partido socialista y los orígenes de la nueva izquierda, Tesis doctoral. Universidad Nacional de La Plata, Facultad de Humanidades y Ciencias de la Educación, La Plata, 2007, 35.
} 
que era la clase trabajadora, con ayuda de ciertos medios provistos por el socialismo, la protagonista de su propio destino. En un artículo titulado "Negación de las leyes obreras", se afirmaba que "Las leyes obreras, [son] fruto de la inteligente y tesonera acción política y sindical de la clase trabajadora..." Aquí los actores centrales eran los trabajadores con conciencia de clase, que, ya sea a través de la lucha sindical o de la representación parlamentaria -seguramente como socialistas-, habían presionado y conseguido la promulgación de leyes.

El hecho de que José Guevara, dirigente de origen trabajador con quince años de trayectoria en el partido, varias veces secretario de la FSC y diputado provincial y director de Tribuna Socialista al momento de su asesinato en septiembre de 1933 a manos de grupos legionarios, luego de su muerte haya sido elevado a la figura de mártir por el socialismo de Córdoba, refuerza la intención del partido de identificarse con la causa proletaria. En el mismo sentido puede interpretarse la denominación de un Centro Femenino con el nombre de Carolina Muzilli, obrera costurera de Buenos Aires que defendió los derechos de la mujer trabajadora y que en 1917 murió en Córdoba. ${ }^{42}$

Si a nivel nacional los líderes muertos y vivos destacados eran Justo, Repetto, Dickmann, Ghioldi o Bravo, acá el referente elegido, en parte por un hecho cruento, fue el de uno de los socialistas locales más antiguos, pero también un simple empleado autodidacta que perdió la vida por su compromiso partidario. ${ }^{43}$ En la FSC, su figura también fue erigida como un símbolo en la lucha contra un fascismo primero vernáculo y luego trasladado al ámbito internacional y nacional. Por el lado de la disidencia juvenil izquierdista, su nombre fue utilizado para bautizar al Centro Juvenil "Juventud Obrera José Guevara", de orientación socialista obrera.

De todas maneras, el socialismo de Córdoba se asemejaba bastante al nacional cuando los tiempos eleccionarios apremiaban, puesto que la interpelación a los trabajadores como clase se difuminaba y dejaba lugar al llamado en cuanto ciudadano, ampliando la convocatoria a todos "los hombres amantes de la libertad y el trabajo", fueran obreros del músculo o de la mente. ${ }^{44}$

Desde 1933 hasta la mitad de 1935, la transcripción en Tribuna Socialista de teorizaciones y lineamientos doctrinarios del partido no eran comunes, pero a través de las citas a Marx, del Valle Iberlucea y el referente de la Revolución Francesa Babeuf acerca de una revolución del proletariado organizado que destruyera las clases, la FSC sentaba una posición más cercana a los sectores de izquierda. Asimismo, el periódico reproducía artículos de legisladores nacionales como Guillermo Korn o el dirigente gráfico Luis

\footnotetext{
${ }^{41}$ Tribuna Socialista, 28 de febrero de 1935, p. 1.

42 Tarcus, op. cit., 451-452.

43 Guevara fue asesinado en ocasión de un acto socialista. Antes había sido objeto de una serie de hechos intimidatorios. Por lo menos hasta 1948 el PS de Córdoba realizó actos en su memoria. Tribuna Socialista, 28 de septiembre de 1934, pp. 1-4; 27 de septiembre de 1935, p. 1; La Voz del Interior, 28 de septiembre de 1948 , p. 9.

${ }^{4}$ Tribuna Socialista, 24 de octubre de 1935, pp. 3 y 4. Como bien apunta Daniel James, el socialismo compartía con los demás partidos políticos la apelación a la incuestionada ciudadanía política liberal e individual escindida de la esfera económica y social de la sociedad civil. Al respecto, el peronismo constituyó una ruptura al asociar en su retórica democracia con justicia social y posicionar a los sindicatos representantes de la clase trabajadora- como interlocutores privilegiados del Estado. James, op. cit., 29-31.
} 
Ramiconi (también convocados para los actos del $1^{\circ}$ de mayo), quienes apoyaban la coordinación de la política socialista con la acción gremial. ${ }^{45}$

Sin embargo, luego de las definiciones doctrinarias y en política gremial del VII Congreso Extraordinario del Partido Socialista, celebrado en mayo de 1935 en Capital Federal, en torno a un mayor disciplinamiento del movimiento juvenil y sujeción y desplazamiento del ala sindical en las filas socialistas, ${ }^{46}$ el cariz de la FSC y de Tribuna Socialista cambiaron. A nivel de estructura partidaria, hubo una retracción del accionar socialista en materia sindical: la Comisión Gremial fue reemplazada por un encargado de acción gremial y cooperativa, que era miembro de la JE. En marzo de 1937 fue constituida la Comisión Socialista de Información Gremial. Por su parte, el periódico se adaptó a la nueva situación desde mediados de 1935, con reproducciones de artículos de La Vanguardia, de Juan B. Justo y de referentes de la línea oficialista del partido, como Enrique Dickmann y Rómulo Bogliolo, incentivándose la lectura del diario y de Revista Socialista. $^{47}$

Lo anterior muestra que, a partir de 1935 es notable la decisión de la FSC de acomodarse a los lineamientos nacionales en materia sindical, pero esta decisión estratégica parece no ser óbice para la continuación de la representación socialista en la arena gremial. De hecho, la escisión de 1937 del PSO tuvo pocas repercusiones en Córdoba, en el sentido que pocos afiliados se separaron. Entre los nombres más reconocidos se encontraban Deodoro Roca y Adelmo Montenegro. ${ }^{48}$ En otras palabras, la ruptura del PSO, que se debió a un reclamo por izquierda de mayor gravitación de lo sindical en el partido, tuvo un asidero poco genuino en Córdoba, considerando sus referentes y las características plebeyas del partido.

\section{Los espacios del socialismo en el mapa sindical}

Entre 1931 y 1935 el PS de Córdoba ganó cargos legislativos, promovió leyes para aminorar la crisis, apoyó conflictos obreros, colaboró con la organización del sindicato maderero, de escoberos y Oficios Varios, y su local central se convirtió en sede de los

\footnotetext{
${ }^{45}$ Tribuna Socialista, 1 de mayo y de junio de 1933, p. 4 y 1 y 3, respectivamente; 28 de febrero de 1935 , p. 6; La Voz del Interior, 3/5/35, p. 13. Ambos dirigentes luego conformaron el Partido Socialista Obrero.

${ }^{46}$ Tribuna Socialista, 20 de junio de 1935, p. 2. Por las adhesiones al PSO, en 1938 la cúpula nacional reconocía haber tomado medidas disciplinarias contra afiliados de un centro de la provincia de Córdoba, al tiempo que el centro de Laboulaye proponía para el próximo congreso partidario que "se considere la posibilidad de un entendimiento, para unificar las fuerzas de izquierda". Partido Socialista, XXIV Congreso Ordinario (XXXII Congreso Nacional), Buenos Aires, junio de 1938, 12, 33 y 96.

47 Tribuna Socialista, 4 de julio de 1935, pp. 2 y 7; 31 de agosto de 1935, pp. 3 y $5 ; 24$ de octubre de 1935 , pp. 7-8 y 5 de diciembre de 1935, p. 1; Federación Socialista Cordobesa, XI Congreso Ordinario (XIII Provincial) que se realizará en la ciudad de Córdoba, los días 1 y 2 de abril de 1939, 9, 25 y 32 . Resulta llamativo que desde los mismos Congresos de la FSC se le exigiera al periódico "un carácter más combativo". La Vanguardia, 1 de enero de 1937, p. 7.

${ }^{48}$ El País, 15 de mayo de 1938, p. 1; La Voz del Interior, 1 de mayo de 1938, pp. 13 y 16.
} 
mismos, más el de sastres. ${ }^{49}$ Esta mayor visibilidad y actuación pública favorable a los trabajadores seguramente brindó prestigio al partido y atrajo cuadros gremiales.

Como mencioné más arriba, la FSC acompañó su interpelación a la clase trabajadora con acciones concretas tendientes a su organización sindical y su incorporación al partido de clase que el socialismo promulgaba ser. Al respecto, reitero el activo accionar de la Comisión Gremial Socialista, aconsejando e interviniendo en la conformación sindical. Así, se incentivaba y asesoraba la formación de sindicatos de oficios varios en La Para, La Francia y Villa Fontana y de estibadores en Marull y Balnearia. Además de la preocupación por las problemáticas del chacarero y del trabajador rural (crédito agrario, subdivisión y producción de la tierra, precio de los cereales, etc.). Esto significaba que la franja este y sureste y sur de la provincia, perteneciente a la zona agropecuaria económicamente más dinámica, era la que más interés y preocupación suscitaba en las filas socialistas, y por la que competían en influencia sindical y/o política con comunistas y radicales. ${ }^{50}$

Hacia 1935, existían dos centrales obreras locales: la Federación Obrera Local (FOL), de inclinación anarquista y que nucleaba a gastronómicos, gráficos y panaderos y sindicatos cercanos al socialismo, como los sastres, costureras y anexos; y la Unión Obrera Provincial (UOP), de orientación comunista. Este mapa se completaba con la intervención indirecta de la Comisión Gremial Socialista, referida más arriba. ${ }^{51}$

Durante los gobiernos radicales (1936-1943), en líneas generales podemos decir que los socialistas predominaron en los gremios del sector terciario y de servicios (empleados de comercio, ferroviarios, tranviarios), mientras la prédica comunista fue preponderante entre los obreros gráficos y de la producción (construcción, metalurgia y alimentación), que cubrían el mayor porcentaje de la actividad industrial. En agosto de 1935, el cambio de la estrategia comunista de clase contra clase a la formación de los frentes populares permitió el acercamiento entre los sindicatos comunistas y socialistas y la instalación en el ámbito gremial de la necesidad de unidad. ${ }^{52}$

Luego de la extensa huelga de albañiles y paro general de enero de 1936 con epicentro en Capital Federal y repercusión en el resto del país, una fortalecida UOP convocó a un Congreso Sindical Provincial al que invitó a todos los sindicatos y agrupaciones gremiales para mediados de febrero en Villa María, con el objetivo de disolver la UOP para así lograr la unidad provincial y nacional. Con la oposición y autoexclusión de la FOL, el Congreso logró reunir a sesenta y tres delegados de cincuenta y ocho organizaciones gremiales de toda la provincia y resolvió la conformación de un

\footnotetext{
${ }^{49}$ Federación Socialista Cordobesa, IX Congreso Ordinario (XI Provincial), que se realizará en la ciudad de Córdoba, 26, 27 y 28 de octubre de 1934. Informes, pp. 73-74; Tribuna Socialista, 17 de julio de $1936,7$.

${ }^{50}$ Tribuna Socialista, 15 de enero de 1935, pp. 4-6; 28 de febrero de 1935, pp. 5-6; 31 de agosto de 1935 , p. 4. Acerca del accionar comunista durante los años '30 en ciudades de la "Pampa Gringa" como Río Cuarto, Villa María y San Francisco, véase Mariana Mastrángelo, Rojos en la Córdoba obrera 1930-1943, Buenos Aires, Imago Mundi, 2011; Ofelia Pianetto, "Sindicatos y política en Córdoba (1930-1943)", César Tcach (coord.), Córdoba bicentenaria. Claves de su historia contemporánea, Córdoba, CEA-UNC, 2010, 237. Es importante señalar que el radical Sabattini ganó las elecciones a gobernador con el inestimable apoyo de la población de las zonas de tardía colonización.

${ }^{51}$ La Voz del Interior, 13 de febrero de 1936, p. 5; Pianetto, op. cit., 236.

${ }^{52}$ Tribuna Socialista, 27 de septiembre de 1935, p. 5.
} 
ideológicamente heterogéneo Comité Pro Unidad Sindical, que, en un nuevo congreso en octubre, sería reemplazado por una Central Obrera. Solo seis sindicatos de la ciudad de Córdoba estuvieron representados en el Congreso: Unión Ferroviaria, Federación Gráfica, y los sindicatos de la madera, de metalúrgicos, de sastres y mosaístas. El Comité Pro Unidad estuvo integrado por los socialistas Miguel Ávila y Horacio Villarreal y se alineó con la política sindical de la flamante CGT Independencia (liderada por socialistas y comunistas), y por la formación de un Frente Popular. Si bien los comunistas habían transigido la disolución de su central en pos de la unificación obrera, los socialistas también lo hicieron luego de su XXIII Congreso Ordinario Nacional, cuando a mediados de 1936 viraron del rechazo al apoyo al Frente Popular. ${ }^{53}$

En octubre de ese año, dicha alianza sindical organizó un congreso obrero que resultó en la fundación de la Central Obrera Provincial que adhirió a la CGT Independencia ${ }^{54}$ Por el momento desconozco su trayectoria pero es probable que al poco tiempo fuera reemplazada por la Federación Obrera Provincial (FOP). Su comisión directiva de 1938 refleja el equilibrio de fuerzas entre comunistas y socialistas producto de la política frentista, con una importante presencia de dirigentes del gremio de la construcción, liderado por los primeros. El secretario general Cruz Ramírez, el tesorero Roque Guillén y los vocales Carlos Pérez, Enrique Viccini (obreros de la construcción) y Carlos Céliz (gráfico) eran comunistas; mientras que el prosecretario Antonio Gómez (albañil), el protesorero Julio Rodríguez (maderero) y los vocales Miguel Ávila (secretario general de los sastres), Pedro Magallanes (trabajador del calzado) y Antonio D'Elía (sastre) militaban en la FSC. Los tres primeros socialistas a la vez conformaban la Comisión Socialista de Información Gremial. ${ }^{55}$ Del resto de la comisión directiva (Domingo Zaragoza -construcción-, Hernán Luna, Samuel Edwards, Fernando Vaisbein y Orfeo Moro) desconozco su inclinación partidaria. Se reunían en la Casa del Pueblo, ubicada en la calle 25 de mayo 286. Esta unidad entre socialistas y comunistas se mantuvo hasta que los últimos pretendieron alinear la central a la política soviética de neutralidad (por el pacto de no agresión entre la Unión Soviética y Alemania firmado en agosto de 1939). En consecuencia, en octubre de 1940 los socialistas fundaron una nueva entidad: la Comisión Cooperadora de la CGT. Allí estaban representados, entre otros, los dos sindicatos ferroviarios (La Fraternidad y Unión Ferroviaria), el del calzado y los empleados de comercio. $^{56}$ Por su parte, los comunistas continuaron en la FOP, más allá del intento de la CGT -que integraba- de disolverla por decreto. Esta división repercutió debilitando la representación sindical, a pesar de la coincidencia en las demandas. Así, por ejemplo, en noviembre de 1940 tanto la CGT como la FOP presentaron -por separado- similares

\footnotetext{
${ }^{53}$ La Voz del Interior, 1 de febrero de 1936, p. 9; 14 de febrero de 1936, p. 8; 16 de febrero de 1936, p. 11, 19 de febrero de 1936, p. 8; Tribuna Socialista, 21 de agosto de 1936, p. 6; 17 de julio de 1936, pp. 1 y 6.

${ }^{54}$ Ferrero, op. cit., 96-97; César Tcach, "Retrato político de la Córdoba de los treinta", César Tcach (coord.), Córdoba bicentenaria. Claves de su historia contemporánea, Córdoba, CEA-UNC, 2010, 185-215.

${ }^{55}$ El País, 20 de abril de 1938, p. 12 y 10 de abril de 1938, p. 7; Federación Socialista Cordobesa, XI Congreso Ordinario (XIII Provincial) que se realizará en la ciudad de Córdoba, los días 1 y 2 de abril de 1939, 32; Torcuato Di Tella, Perón y los sindicatos. El inicio de una relación conflictiva, Buenos Aires, Ariel, 2003, 132.

${ }^{56}$ La Voz del Interior, 20 de noviembre de 1940, p. 11; Ferrero, op. cit., 101.
} 
exigencias al gobierno provincial referidas a la necesidad de promover la obra pública como paliativo ante el desempleo. ${ }^{57} \mathrm{El}$ acercamiento entre ambas centrales obreras locales se produjo recién un año después, cuando el ataque de Alemania a la Unión Soviética en junio de 1941 condujo nuevamente a los comunistas a sumarse al frente antifascista. Sin embargo, el golpe de junio de 1943 encontrará a los socialistas en la Comisión Cooperadora de la CGT, liderada por el ferroviario Bruno Herrera, y a los comunistas en la por ese entonces UOP, luego reemplazada por el Comité Interclasista. ${ }^{58}$

\section{Conclusiones}

Este artículo se propuso mostrar, a través de un caso local, un entramado político y prácticas de actores concretos a nivel micro, con la intención de aportar al entendimiento y la reflexión de ciertos procesos históricos, como son la construcción de identidades políticas y los factores que influyeron en la peronización (o no) de las dirigencias sindicales.

El trabajo señala ciertos puntos comunes del PS en los años treinta, como la apelación a la figura del legislador (que no necesariamente ocupaba cargos partidarios preeminentes) como palabra autorizada públicamente o la presencia de líderes aglutinantes o que encarnaran el ideal socialista que el partido quería transmitir. Si a nivel nacional se trató de intelectuales o pensadores que imprimieron el norte del PS, en la provincia el líder fue un dirigente de origen obrero asesinado y convertido en mártir. En efecto, la ausencia de intelectuales entre los principales cuadros en la configuración primigenia y posterior del partido o la centralidad referencial que se construyó en torno a la figura de José Guevara luego de su asesinato en 1933 se constituyeron en las notas características de la FSC. También habría que sumarle el ser un partido carente de tradición intelectual, más preocupado por las acciones y por llevar a cabo lo que otros solamente teorizaban o pregonaban.

Las vinculaciones que los dirigentes sindicales fueron entablando; las posiciones que fueron ganando entre los cuadros partidarios, en cargos electorales o en los órganos de prensa; y la conformación primigenia y la tradición -plebeya y aintelectual- en la que se asentaba el partido constituyen variables explicativas del nivel de gravitación de la agenda proletaria y la consideración que se hacía de la clase trabajadora en las filas del PS local.

La interpelación al trabajador pensante como protagonista político social, con capacidad propia para transformar la realidad, y la incorporación y participación concreta de sus exponentes "más conscientes", los sindicalistas, en la vida diaria del partido, seguramente coadyuvaron a la conformación de una identidad política socialista sólida entre los dirigentes sindicales de la FSC, condiciones que parecen no haberse dado a nivel nacional o en otros puntos del país, como Tucumán o Mendoza. ${ }^{59}$ En Córdoba nos

\footnotetext{
${ }^{57}$ La Voz del Interior y El País, 9 de noviembre de 1940, p. 11 y 10 respectivamente; La Voz del Interior, 20 y 29 de noviembre de 1940, p. 11 y 9 respectivamente; El País, 29 de noviembre de 1940, p. 7.

${ }^{58}$ Ferrero, op. cit., 101 y 103.

59 Jessica Blanco, "Entre espacios naturales y concedidos. Los socialismos en Mendoza y los trabajadores, 1937-1943”, Coordenadas. Revista de Historia Local y Regional, 5:1, Río Cuarto, 2018, 61-81.
} 
encontramos con una Federación bastante cohesionada y que por su composición, daba cabida a la problemática obrera y sindical. De ahí que la ruptura del PSO fue prácticamente inocua en territorio mediterráneo.

La FSC nos brinda una imagen de un partido que desde los años veinte logró sobrevivir a dos fluctuaciones políticas intensas como fueron la escisión del Partido Socialista Independiente en 1927 y el levantamiento de la abstención radical en 1935. Asimismo, no debe subestimarse el conflicto con el ala juvenil que se percibe en la declaración de Fermín Simón, que dio nacimiento al Centro Juvenil José Guevara.

Por otro lado, la bajada de tono en la dinámica gremial de 1935 y la escisión por izquierda del PSO parecieron no afectar su reputación en la arena sindical. Sin embargo, la conformación o rechazo a los Frentes Populares en la coyuntura de la guerra mundial perturbó los alineamientos sindicales entre socialistas y comunistas, ocasionando divisiones que debilitaron la representación gremial ante la patronal y los poderes públicos.

El luchar política y gremialmente como socialistas, tanto en el partido como desde el sindicato, se reforzó en el periodo previo a la emergencia del peronismo en un contexto de competencia obrerista, por parte de un PC muy presente y activo en los sindicatos de actividades primarias y secundarias, y de los gobiernos radicales.

Así, en Córdoba, podemos decir que tanto el PS como el PC se auto representaban y eran partidos obreros, características que fortalecieron identitariamente a sus referentes sindicales y que desde la perspectiva de las subjetividades políticas seguramente contribuyeron al rechazo de las ofertas sociales e intentos cooptativos del gobierno militar y del peronismo. Esta conclusión invita al ejercicio comparativo entre los elementos clave de las subjetividades de izquierda y la peronista, como un desafío pendiente para próximos trabajos.

\section{Referencias bibliográficas}

\section{Impresas}

-Martín Bergel, "Flecha, o las animosas obsesiones de Deodoro Roca", Deodoro Roca. Obra Reunida. Vol. IV. Escritos políticos, Córdoba, 2012, 23-69.

-Michel Bertrand, "De la familia a la red de sociabilidad", Páginas, Universidad Nacional de Rosario, 4:6, Rosario, 2012, 47-80.

-Jessica Blanco, "El Partido Socialista, el sindicalismo y las competencias en torno del obrerismo en la Córdoba radical (1936-1943)", ponencia presentada en VIII Reunión del Comité Académico de Historia, Regiones y Fronteras, Asociación de Universidades Grupo Montevideo (AUGM), Montevideo, 2017.

-------, "Del protagonismo al ocaso. Las dirigencias sindicales comunistas de Córdoba ante la irrupción del peronismo (1936-1948)", Izquierdas, Instituto de Estudios Avanzados de la Universidad de Santiago de Chile, 28, julio de 2016, 1-26.

---------, "Entre espacios naturales y concedidos. Los socialismos en Mendoza y los trabajadores, 1937-1943”, Coordenadas. Revista de Historia Local y Regional, 5:1, Río Cuarto, 2018, 61-81. 
-Hernán Camarero, "El Partido Socialista de la Argentina y sus espinosas relaciones con el movimiento obrero: un análisis del surgimiento y disolución del Comité de Propaganda Gremial, 1914-1917”, Izquierdas, Revista del IDEA-USACH, 22, Santiago de Chile, enero de 2015, 158 179.

-Diego Ceruso, "Apuntes acerca de la experiencia sindical del Partido Socialista argentino entre 1930 y 1943", Hernán Camarero y Manuel Loyola (eds.), Política y cultura en los sectores populares y de las izquierdas latinoamericanas en el siglo $X X$, Santiago de Chile, Ediciones de la Internacional del Conocimiento Ariadna Ediciones (e-book), 2016, 171-188.

---------, "El Partido Socialista y el movimiento sindical tras la conquista de la Confederación General del Trabajo (1935-1937), Páginas, 9:20; Rosario, mayo-agosto 2017, 131146.

, "El Partido Socialista y la cuestión gremial. Debates internos durante la primera mitad de la década infame", Archivos de historia del movimiento obrero y la izquierda, V:10, Buenos Aires, marzo 2017, 119-139.

-Club Atlético San Isidro, 1970.

-Hugo del Campo, Sindicalismo y peronismo. Los comienzos de un vínculo perdurable, Buenos Aires, Clacso, 1983.

-Torcuato Di Tella, Perón y los sindicatos. El inicio de una relación conflictiva, Buenos Aires, Ariel, 2003.

-Diario El País

-Diario La Vanguardia

-Diario La Voz del Interior

-Louise Doyon, Perón y los trabajadores. Los orígenes del sindicalismo peronista 1943-1955, Buenos Aires, Siglo XXI, (2006 [1978]).

-Alejandro Dujovne, "El Partido Socialista de la provincia de Córdoba 1933-1936. Una lectura política desde el periódico Tribuna Socialista", Documento de trabajo ${ }^{\circ} 2$, Córdoba, Publicación de la Maestría en Partidos Políticos y el Archivo de la Palabra del CEA-UNC, 2003.

-------------, "El Partido Socialista de Córdoba y la Reforma Universitaria, 1917-1948”, Marcela González (ed.), Poder Político y Estrategias Sociales. Córdoba 1900-1950, Córdoba, EDUCC, 2004, 193-234.

-Federación Socialista Cordobesa, IX Congreso Ordinario (XI Provincial), que se realizará en la ciudad de Córdoba, 26, 27 y 28 de octubre de 1934. Informes

-Federación Socialista Cordobesa, XI Congreso Ordinario (XIII Provincial) que se realizará en la ciudad de Córdoba, los días 1 y 2 de abril de 1939.

-Roberto Ferrero, Del mutualismo al Cordobazo. Breve historia del movimiento obrero en Córdoba, Córdoba, Ediciones del Cepen, 2009.

-Joel Horowitz, "Ideologías sindicales y políticas estatales en la Argentina 1930-1943", Desarrollo Económico, 94, Buenos Aires, Ides, 1984, 275-296.

-Daniel James, Resistencia e integración. El peronismo y la clase trabajadora argentina, 19461976, Buenos Aires, Siglo XXI, 2005 [1988].

-Bernard Lepetit, Bernard, "De la escala en historia", Jacques Revel (dir.), Juegos de escalas: experiencias de microanálisis, Buenos Aires, UNSAM, 2015 [1996], 87-114.

-Ricardo Martínez Mazzola, "La neutralidad como problema y como solución. La política gremial del Partido Socialista después de la ruptura sindicalista", Identidades, Universidad Nacional de la Patagonia San Juan Bosco, 1, Comodoro Rivadavia, 2011, 2-20.

-Ricardo Martínez Mazzola y Sebastián Giménez, "Del claustro a la tribuna. Los universitarios reformistas y los partidos políticos en la década del 30", Cuatrocientos años de la Universidad 
Nacional de Córdoba. Libro conmemorativo. Tomo II, Universidad Nacional de Córdoba, Córdoba, 2013, 87-106.

-Mariana Mastrángelo, Rojos en la Córdoba obrera 1930-1943, Buenos Aires, Imago Mundi, 2011.

-Miguel Murmis y Juan Carlos Portantiero, Estudios sobre los orígenes del peronismo, Buenos Aires, Siglo XXI, 2004[1971].

-Partido Socialista, XXIV Congreso Ordinario (XXXII Congreso Nacional), Buenos Aires, junio de 1938.

-Partido Socialista, XXXIII Congreso Nacional (XXV Congreso Ordinario), Buenos Aires, julio de 1940, Talleres Gráficos La Vanguardia.

-Periódico Tribuna Socialista.

-Ofelia Pianetto, "Sindicatos y política en Córdoba (1930-1943)", César Tcach (coord.), Córdoba bicentenaria. Claves de su historia contemporánea, Córdoba, CEA-UNC, 2010, 217-248.

-Lucas Poy, "El Partido Socialista y las huelgas: una relación incómoda. Un análisis de las posiciones partidarias en los primeros años del siglo XX", Archivos de historia del movimiento obrero y la izquierda, CEHTI, 6, Buenos Aires, 2015, 31-51.

-Horacio Tarcus (dir.), Diccionario Biográfico de la Izquierda Argentina, Buenos Aires, Emecé Editores, 2007.

-César Tcach, "Crimen político en barrio Güemes", La Voz del Interior, 24 de septiembre de 2013.

-----------, "Retrato político de la Córdoba de los treinta", César Tcach (coord.), Córdoba bicentenaria. Claves de su historia contemporánea, Córdoba, CEA-UNC, 2010, 185-215.

---------, "Un radicalismo exitoso en la Argentina de los treinta. El caso del sabattinismo cordobés", Boletín Americanista, 57, Barcelona, 2007, 133-156.

-Juan Carlos Torre, La vieja guardia sindical y Perón. Sobre los orígenes del peronismo, Buenos Aires, Sudamericana, 1990.

-María Cristina Tortti, "Clase obrera, partido y sindicatos: estrategia socialista en los años '30", Serie Cuadernos de Historia Argentina, Buenos Aires, Editorial Biblos, 3, 1989, Consultado y disponible en historiapolitica.com, http://historiapolitica.com/datos/biblioteca/tortti4.pdf [último acceso: 20/09/2017]

-----, El viejo partido socialista y los orígenes de la nueva izquierda, Tesis doctoral. Universidad Nacional de La Plata, Facultad de Humanidades y Ciencias de la Educación, La Plata, 2007.

-Gardenia Vidal (dir.), Reseña Biográfica de dirigentes que interpelaron al mundo del trabajo en Córdoba 1900-1950, E-Book, Córdoba, 2014.

-XX Congreso Ordinario (XXV Congreso Nacional). Informes Comité Ejecutivo Nacional, Grupo Parlamentario y Comisión de Prensa, Talleres Gráficos La Vanguardia, Buenos Aires, 1929

\section{Digitales}

-Requena, Pablo; voz Gregorio Bermann; on line; disponible en http://culturasinteriores.ffyh.unc.edu.ar/ifi002.jsp?pidf=PN6\&po=DB [06/02/2018]

-Requena, Pablo; voz Arturo Orgaz; on line; disponible en http://culturasinteriores.ffyh.unc.edu.ar/ifi002.jsp?pidf=AM3M3A\&po=DB [06/02/2018] ; -http://www.clubtalleres.com.ar/talleres-el-primer-club-argentino-en-viajar-a-paraguay/ ${ }^{1}$ $\mathrm{E}$ 